\title{
Psychosocial Aspects of Honour Killings
}

\author{
Rucha Sule ${ }^{1}$ \\ Aditi Acharya ${ }^{2}$ \\ Avinash De Sousa ${ }^{3}$ \\ 1,2 Senior Resident Doctor, \\ ${ }^{3}$ Research Associate \\ Department of Psychiatry, Lokmanya Tilak Municipal Medical College, Mumbai. \\ E-mail - avinashdes888@gmail.com
}

\begin{abstract}
Honour killings and honour based violence has been reported in most cultures worldwide ranging from Asian countries and the Middle East to incidents in Europe and the United States. The present paper reviews the available literature on these acts and incidences, but from a psychosociocultural perspective. There has been research done on the subject but non leading to firm conclusions. The paper looks at the rubric of honour and what it denotes when we speak in terms of these events. It also posits a few theories available on the causative factors leading to such events. The available research and literature is reviewed with epidemiological data available on honour killings and honour based violence. A special section with reference to killings in India under the Khap panchayat rule is discussed based on the Indian scenario where the authors work. Preventive strategies are outlined and methods to help victims of honour based violence are suggested.
\end{abstract}

Key words : honour killings, honour based violence, sexual violence, khap panchayat.

\section{INTRODUCTION}

The past decade has seen a linear increase in acts of violence against women which are often committed under the guise of 'honour' [1]. Many reports in the media and news as well as researchers have viewed these acts of 'honour killings' (HK) or 'honour based violence' (HBV) through a religious, feminist based or cultural lens. It is our firm belief that while culture and religion may lie at the heart of many such acts they also have psychological and masculine motivational underpinnings [2]. Honour is most often defined as 'a virtue or character trait associated with integrity, sound moral values and character and altruism along with a strong desire to stand up for what one feels right and to protect others' [3]. HBV and HK are acts of violence, sometimes resulting in murder, committed almost always by male family members (or members of a particular community / caste / sect) against female family members (or female members of a particular community / caste / sect) who are presumed to have brought dishonour upon the family [4]. The use of the word 'honour' for such dishonourable acts is unfortunate 
as these acts are nothing but barbaric and shameful acts of murder committed by brutal, feudal minded people [5-6].

The Universal Declaration of Human Rights (UDHR) [7] set forth by the United Nations, recognizes that the inherent dignity and equal and inalienable rights of all members of the human family is the foundation of freedom, justice and peace in the world [8]. Amongst other rights, the UDHR states that 'All humans are born free and equal in dignity and rights. These rights and freedoms are set forth without distinction of any kind, such as race, colour, sex, language, religion, social origin, property, birth or other status. Everyone has the right to life and liberty. No one shall be subjected to torture or to cruel, inhuman or degrading treatment or punishment. It also mentions that men and women of full age, without any limitation due to race, nationality or religion, have the right to marry and to form a family. They are entitled to equal rights as to marriage, during marriage and at its dissolution' [8]. HK and HBV, thus, constitute the gravest disregard of universal human rights and a massive violation of the fundamental rights of a human being.

\section{METHOD OF CONDUCTING THIS REVIEW}

For identifying articles that focused on HK and HBV, the terms 'honour killings', 'honour based violence','violence against women','honour and domestic violence', or 'honour and violence' were used. For identifying articles that focused on specific terms, like 'forced suicide', 'honour and religion', 'honour and child marriage','eloping couples', 'psychosocial issues in honour killings' and other terms were used. These two search strategy results were combined with an "and" statement in the following data bases with the time frame being specified from 1980 through 2015. The databases used were Medline and Pubmed. There was a dearth of literature and systematic research on the problem noted in these searches and few articles $(<30)$ were available. Using the same keywords a search was carried out in a general search engine (Google) and an academic search engine (Google scholar). A number of bachelor's thesis on the subject and a number of non pubmed indexed open access journals had papers on the subject that were reviewed as well and the most relevant ones were chosen for the studies. A number of books have been written on the subject and the most relevant and recent books on the subject were specially ordered and reviewed for this paper. The review of this paper is supplemented with the personal clinical experience of all the authors who work regularly with a non-governmental organization that deals with victims of domestic violence where such issues come up and thus have further insight into the problems faced by them. One of the authors (Avinash De Sousa) has also spoken to psychiatrists working in different states where HK and HBV is common in India to colleagues in other parts of the world (Pakistan, Jordan, Saudi Arabia and Syria) to get a better understanding of the ground reality of the problem. All the authors are mental health professionals working in either a tertiary hospital and medical college or a private clinic setting.

\section{HISTORICAL OVERVIEW OF HBV AND HK}

The practice of HK has a long genealogy wrested in human history and evolution. It has been linked to the emergence of patriarchal social structures across Europe, Asia and India within which the 'honour' of the family and the community came to be inextricably bound with the sexuality of its women [9]. The worth of a community 
is vested in its land and women and thereby notions of shame and honour came to be linked to these possessions [10].

Accounts published by British colonialists in India have documented the customary practice of honour killing in these times and mentions that HK was an integral part of a detailed code of honour that regulated tribal social relations [11]. The origins of $\mathrm{HK}$ in India can be traced to the pre-Islamic tribal culture of Baluchistan and the Northwest frontier province [12]. Migrating tribes from Baluchistan carried their tribal code across the border into upper Sindh and southern Punjab and Haryana where the practice of HK and HBV, rooted in ancient custom, continues to this day [12]. Even in their rule the British did attempt, albeit with moderate success, to stop the HK of women. Documents records that Charles Napier, the British governor of Sindh, let it be known that all 'karo kari' (karo refers to the adulterer and kari ro the adulteress) killings would be punished with death [13]. In fact the banning of HK and HBV led to an increase the incidence of 'female suicides' being reported from many villages across the province. British law at that time mentions that a fine was to be levied on the entire village where this suicide happened (as it was suspected to be HK masked as female suicide), and all of the relatives of the dead woman's husband were to be forcibly banished to exile in Karachi [14]. Thus according to historical narratives and anthropological studies, the killing of women to restore male honour and maintain patriarchal structures has been taking place for centuries in lands that were the cradles of world civilisations in agrarian societies (an agrarian society is any society based around producing and maintaining crops and farmland), in tribal societies, in some parts of Southern Europe as well as in countries across the Atlantic [15].

In fact, some countries of the world include specific provisions in the law that place HK and HBV in a category of its own. For example penal codes in Jordan, Lebanon and Syria entirely absolve those men from the penalty of their actions who kill 'adulterous' women caught red handed committing an 'offence' [16]. 'Sharia law' literally means a religious code of life. It is used to refer both the Islamic system of law and totality of an Islamic way of life [17]. One of the Sharia laws state that, 'A Muslim will be forgiven for murder of (a) an apostasy (means renunciation and criticism of / or opposition to a person's former religion in a technical sense and without pejorative connotation) (b) an adulterer (c) a highway robber', thus making vigilante street justice and HK acceptable [17].

The value of a woman historically as chattel was closely related to the other seemingly more elevated aspect of her status in society, that is, as a repository of male and tribal honour [18]. For any woman, virginity as an unmarried girl and her chastity as a married woman defined, on the one hand, her value and role to establish the paternity of the tribe's offspring [18]. In the case of adultery or illicit sexual relations, guilty of devaluing herself and undermining her husband's (or father's) social standing, she forfeited her utility and her right to life [18].

\section{SOCIO-CULTURAL ASPECTS OF 'HONOUR'}

In cultural connotations, the family's 'honour' is valued by the girl's or the woman's social and sexual behaviour, in her virginity and is therefore dependent on how well she can manage the deeply rooted traditional norms that describes what is acceptable or not. The honour values are set by the cultural, traditional and patrilineal values well embedded in the social behaviour [19-20]. In a patriarchal structure the oldest male is the head of the family and holds the power, and therefore has the control over the subordinate women and children [19]. However, in a patrilineal society, the 
blood relation persists throughout the whole life, that means that the paternal family has a responsibility even after marriage. This responsibility has a function of support for the woman and prevention of negative treatment from the husband or his family, but it also means that she is controlled by both her paternal family and her marital family [21].

A woman's chastity has the function of a symbolic capital for the family in many societies and therefore needs to be protected. The woman needs to be delivered 'untouched' to her husband [22]. Sexuality in women is therefore central and is monitored by both the family and the community. The family's reputation and honour is valued according to the behaviour of girls and women and how they manage traditional ethical norms of the society in which they live [23]. When shame is brought upon the family, the family honour is lost [23]. It has been found that behaviour norms are more relaxed in urban settings and modern cultures as compared to rural settings and primitive cultures [24].

Social norms are the set of rules of what is acceptable behaviour in the specific society, and becomes part of the culture [25]. The social and the sexual behaviour of women are regulated within the social norms. Rebellious behaviour and not obeying the ethical and social rules, including inappropriate or disrespectful behaviour has been considered a violation of family honour [25]. Premarital sex, adultery, becoming pregnant out of wedlock and prostitution were all situations that caused harm to family honour and were acceptable within the sexual norms [26]. The religious belonging was also important and marrying outside one's religion would be violating not only the family honour but also religious law in some cases [17]. Researchers have described 'honour' as a mentally constructed power, based on gender and sexuality. The reputation of the girl is worth everything, even more than her wellbeing or life [26].

\section{CAUSATIVE FACTORS AND THEORIES OF HK AND HBV}

In most regions where $\mathrm{HK}$ and $\mathrm{HBV}$ are common, women know that there is no alternative available but to follow the norms and rules which are set as any violation can make the family may feel compelled to restore its honour. This can be in form of forcing the woman into an early marriage, restrictions in daily social life and in the most extreme form, a forced suicide or murder [27].

$\mathrm{HK}$ is as incomprehensible to many as it is tragic and ghastly. One may often wonder what makes seemingly sane people kill their own wives and daughters, these being human beings they have given birth to and spent many years parenting and nurturing - and all this just for the sake of family reputation [27]. From an evolutionary biology standpoint, the concept of HK is not conceivable as if a post Darwin view hold true, human beings are least likely to kill people with whom they share a genetic commonality (their offspring) [28].

Psychological theorists link HK and HBV to an extreme form of 'status anxiety' - where there exists a fear of losing one's status and the desire to salvage it [29]. Pathological insecurity has been noted in region where HK occurs along with a constant pressure to adhere to strict social norms and rules with a fear of losing face, and being ostracised by the community [29]. Disobeying social convention brings the risk of losing one's identity as a member of a particular social group. HK and HBV just like war, stems from a sense of existential vulnerability and incompleteness and this sense of vacuum creates the need for status and saving face along with the paranoid fear of losing the same [28]. 
In many cases of HK or HBV reported, it is only a rumour, suspicion or heresay about shameful behaviour that triggers violence. HK are usually planned and is something primitive societies expect to happen and even exert pressure on individuals for it to happen [30-31]. Researchers have found that the tolerance of violence was higher amongst fathers who had a low status occupation and mothers who had a low level of education [32]. Those who had witnessed violence at some part of their lives justified honour violence and honour killings to a higher extent [32]. Forced marriages of underage children under social pressure from the community often occur in the family's beliefs of protecting them from honour related stigma [33]. Refusing to stay within these restrictions, to marry a partner of their own choice, refusal to marry or escaping a forced marriage, was found to bring shame upon family and violate the family's honour and often led to punishment [33].

Women and girls can be killed for a variety of behaviours, which may include talking to unrelated males, consensual sexual relations outside marriage, being a victim of rape, seeking a divorce, or refusing to marry the man chosen by one's family. Even the suspicion of a transgression may result in a killing. Women may also be assaulted physically but not killed [34]. No research till date is available on the neurobiological basis or pathways that may lead to HK and HBV and is definitely an area for future research.

$\mathrm{HK}$ and HBV are thus derived from various routes. There are psychological theories coupled with cultural and religious derivations. This is intertwined with social pressure soaked in rituals and community norms. Masculine dominance and exposure to such violence at an early age may be propelling factors towards the same. No research on the genetic or epigenetic contributions to $\mathrm{HK}$ and $\mathrm{HBV}$ are available for us to comment on the same. Thus a multifactorial pathways adorn the trajectories that lead to both HK and HBV.

\section{PARENTING AND ITS ROLE IN HK AND HBV}

Research suggests that experiences of abuse and maltreatment by parents is associated with a greater endorsement of own aggressive behavior later in life and that experiences of harsh discipline are associated with a greater likelihood of accepting honor killings [35]. Harsh discipline by the father was associated with greater acceptance of $\mathrm{HK}$ and the effect was limited to boys only [35]. It suggests that an authoritarian and patriarchal disciplining style of the father increases the likelihood that their sons are prepared to accept that killing a woman to protect the honor of their family is justifiable [36]. Effective management of any childhood abuse and maltreatment and even desensitization after exposure to violence can also go a long way in bringing about an attitudinal change regarding violence [36].

\section{EXTENT OF THE PROBLEM AND EXISTING RESEARCH}

A report submitted by the United Nations General Assembly [37] concerning cultural practices in the family that reflect violence against women reported that HK have been reported in Egypt, Jordan, Lebanon, Morocco, Pakistan, the Syrian Arab Republic, Turkey, Yemen, and other Mediterranean and Persian Gulf countries. In addition, the migrant communities in Western countries such as France, Germany and the United Kingdom, had also encountered such episodes. Culture and upbringing play a significant role in the development of attitudes towards HK and HBV. In a survey based study done in Islamabad, majority of people surveyed revealed that it was justifiable and 
acceptable to kill one's wife as a mean to save one's honour. The most significant finding was the fact that overwhelming number of men and women did not believe in either forgiveness or divorcing one's wife who has engaged in extramarital sexual relationship [38]. An epidemiological study of HK in Pakistan revealed using newspaper data analysis that over $1950 \mathrm{HK}$ events occurred in the country between 2004 and 2007. In 88\% cases the subjects were married and in $92 \%$ of cases, an extra-marital affair was the reason for the HK. Husbands, brothers, in-laws and close relatives were involved and firearms, strangulations, stabbing and use of an axe were the methods used. The mean annual rate of HK in Pakistan in women between the ages of 15-60 years was found to be 15.0 per million [39].

A multi nation study by World Health Organization (WHO) on women's health and domestic violence showed that $15 \%$ to $71 \%$ women experienced intimate partner violence regularly in their lifetime. Women in Japan were the least likely to have ever experienced physical or sexual violence or both while the greatest amount of violence was reported by women living in rural settings in Bangladesh, Ethiopia, Peru and the United Republic of Tanzania [40]. The United Nations Population Fund (UNPF) [41] report estimated that the annual worldwide total of HK victims may have been as high as 7000. An early study done revealed that in 2002 alone, over 382 people, of whom 245 women and 137 were men, became victims of honour killings in the Sindh province of Pakistan [42]. In Jordan, which is considered one of the most liberal countries in the Middle East, families often have sons who are considered minors, under the age of 18 , to commit the honour killings because a loophole in the juvenile law allows minors to serve time in a juvenile detention centre and they are released with a clean criminal record at the age of 18 [43]. A common form of HK reported in Pakistan is 'karo-kari'. This is type of premeditated HK, which originated in rural and tribal areas of Sindh, Pakistan. The homicidal acts are primarily committed against women who are thought to have brought dishonour to their family by engaging in illicit pre-marital or extra-marital relations. In order to restore this honour, a male family member must kill the female in question. Socio-cultural factors and gender role expectations have given legitimacy to karo-kari within some tribal communities. In addition to its persistence in areas of Pakistan, there is evidence that karo-kari may be increasing in incidence in other parts of the world in association with migration [44-45].

The practice of HK and HBV is more prevalent although not limited to countries where the majority of the population is Muslim. In this regard it must be noted that a number of renowned Islamic leaders and scholars have publicly condemned this practice and clarified that it has no religious basis [46]. Currently, there is no definition of honour-based violence that is appropriate or relevant cross-culturally. This is hardly surprising considering that any such definition would need to represent both cultural and outsider perspectives. However, the absence of a definition does not mean that honour crimes do not exist, or that they are restricted to only some societies. Research on HK and HBV have been done in Bangladesh [47], Turkey [10], South Asia [2], India [48-49], Jordan [43], Pakistan [24] and the Arab world [33]. Research on HK and HBV involves various perspectives, some studies focus on the epidemiology while others focus on the aftermath, still others focus on knowledge, attitudes and beliefs while few have focused on perpetrators and the victims. This may probably be due to the fact that both these groups are not easily available to research. 


\section{HK AND HBV IN INDIA: THE ROLE OF 'KHAP' PANCHAYATS}

At the time of newly gained independence of India, it was felt that the land was difficult to administer due to its wide spread geographic area. The leaders of new independent India believed that people are best left to govern themselves and this was the ideology behind the freedom struggle [50]. Out of this idea of local selfgovernance, the 'panchayat raj' system came into existence. 'Panchayat' literally means assembly (ayat) of five (panch) wise and respected elders chosen and accepted by the local community [51]. 'Khap' (caste) panchayats in some parts of India define their own laws by running their own parallel judicial institution to the courts [52]. This has been commonly reported in media when girls try to marry outside their caste and/or try to elope with their partner [52].

During the past few years, marriages within 'gotra' (clan) of the Jat community have come into the limelight in some states of India. Couples who have eloped have been brutally murdered by the diktats of the elders-these are known as HK. Many such incidents have occurred in Haryana, Western Uttar Pradesh and the rural belt of Delhi. There exists a deep chasm between modernization on one hand and feudal mind sets of people like the 'Khap Panchayats' who force couples who have entered intra-gotra marriages to return to the community fold, even to the extent of forcing the couples to live like siblings. A large number of such wedded couples have even lost their lives. As per their gotra affinity, the Khap Panchayats consider them as brother and sister [52]. They try to legitimize their actions by quoting historical antecedents of uncertain origin to support their practices and are of the opinion that they are an age old institution, having its foundation in the early medieval period [52].

The expectation to uphold the customary rules and regulations in conjugal relations is common to all castes and communities in India. Same gotra marriages are particularly eschewed in most tribal and caste based societies. It is worth noting that patrimony-based gotra system and the marriage norms related to it had been widely prevalent in the entire world during primitive age. Inter-marriage in the same gotra (endogamy) or conjugal relations outside the tribe (exogamy) was prohibited in the clan-based system of primitive stage [53].

In North India, particularly in the agrarian societies, love for someone is not the deciding factor in marriage. Rather caste affiliation and financial status are the determining factors and that are too decided by parents. As in the patriarchal society, the child born out of a marriage, particularly the male child is considered to be the legitimate heir to the father's property. Therefore there is a close interconnection between the conjugal relations and the property relations existing in the society [54]. Monogamy is that form of marriage practice which produces a Yegitimate inheritor', and this is the form which is presently in practice in Haryana and in India [54]. Restrictions were imposed on women so as to produce legitimate heirs to property. The main objective of these restrictions is to control their sexuality and reproduction. To maintain the familial hold over property, to keep property within a particular caste, and to reproduce the production relations that got established on the basis of the caste system, not only the rules and customs related to marriage are promulgated but are also strictly enforced [55]. In Haryana too, the violation of the marriage regulations is considered to be a very serious crime. But death sentence is pronounced for the violation of these norms. This is because the khap panchayats of the Jat community is more organised, powerful and influential in comparison to the village panchayats. They even confront state power [56]. 
If a Jat woman marries a 'lower' caste man - she is often murdered [54]. Such a marriage will elevate the social status of the lower caste and will prove to be an impediment in the continuation of the caste-based exploitation and oppression as these Dalits (lower caste) and other oppressed caste are their subordinates in agrarian relation. Thus, in a majority of cases when a Jat girl marries a Dalit boy, the khap panchayats pronounce death sentence on the couple as a mark of social honour. However, if a Jat boy marries a girl who belongs to the 'lower' castes, he is not killed [54]. The Jat boys are establishing conjugal relations with girls in 'lower' castes from Himachal Pradesh, Madhya Pradesh, Himachal, Jharkhand, etc, as number of girls have declined sharply in Haryana due to female foeticide [57]. But no khap has opposed such inter-caste marriages, though considered to be a taboo in the traditional customs of the Jat society. The reason for this is that even after such an inter-caste marriage, there is no possibility of a change in the status of the bride's family and subsequently of her caste members, since in a patriarchal society the bride's family in any case has a lower status [58]. Murder of couples in love have gone up manifolds after the Hindu Marriage Act and Hindu Succession Act (India), which recognises the legal rights of daughters to ancestral property, came into being. Attempts are being made by legal authorities despite political intereference, community workers and educated masses in certain states with the help of local non governmental bodies to end the barbaric rule of these khap panchayats [56].

\section{PROBABLE SOLUTIONS TO THE PROBLEMS OF HK AND HBV}

Tackling the problem of $\mathrm{HK}$ and HBV requires striking a fine balance between psychoeducational and legal interventions along with interventions at a community and individual level. Honour killings amount often to homicide and murder which are serious crimes under the legal statutes of any nation [59]. In spite of stringent laws, HK and HBV keep happening, further stressing the point that only legislation is not sufficient to tackle the problem. Investigations into the crime and scenario are often slow and biased with issues related to community honour or pride. It is clear that a narrow legal approach, focusing on state legal systems alone unaccompanied by broader, deeper initiatives and understandings are unlikely to change practice in this regard [59]. Dialogue and discourse with religious and cultural tolerance is the most plausible solution that seems workable across cultures [60]. Community discourse and psychoeducation should involve discussion of every aspect of HK and HBV within local communities where they occur. The means shall include radio and television programmes in local languages, Friday sermons and discussions at local mosques, songs, formal and informal education in school, sports and youth clubs, and women's or other community associations [60].

Some authors argue that one can object to crimes of honour from a human rights perspective because they are excessively violent and discriminatory against women, without necessarily arguing that the community's view of sexual propriety is itself objectionable from a human rights perspective [61]. Hence by the use of the community discourse method if even some elements of the religious right can be persuaded not to change their ways altogether but just not to incite/incur honour crimes, that can turn out to be a great step towards eliminating this menace from the society [61]. There is no research towards the treatment, medical or psychotherapeutic of HK perpetrators while there is no dearth of research to suggest that psychological interventions play a role in the management of vicitims of HK and HBV [62]. Going into the details of these interventions and the various studies carried out in this vein is beyond the scope of this review and entails a separate discussion on its own itself. 
The survivors of honour need gender-sensitive health services to cope with the physical and mental health consequences including pregnancy testing, pregnancy prevention (e.g. emergency contraception), abortion services (where legal), STI testing and/or prophylaxis, treatment of injuries, empathetic listening, ongoing psychological support and referral to other services [63]. Depending on the type of HBV, there are diverse consequences for the women's mental health. A quarter of all victims of violence suffer from posttraumatic stress disorders (PTSD); in combination with sexual violence 50\% develop a PTSD [64]. Asian women are under considerable pressure to cover up their experiences of abuse and any related mental health problems. They are frightened of being stigmatized by their communities in which both abuse and mental illness are regarded as weaknesses which might reflect on the family and bring shame and dishonor [65]. Asian women who have been supported in primary care place high value on the support they attain through external validation and acknowledgement of their experience, whether or not any other action is taken [66].

Many countries have guidelines on how to manage case of HBV and domestic violence. It states that prevention, protection and empowerment hold the key to deal with these crimes. Prevention can be achieved by raising awareness and through training the law enforcement agencies, security personnel and other people involved [67]. Research on the root causes and consequences of violence against women helps us to develop effective solutions. Also, there has to be effective monitoring and assessment and this should be facilitated by international agreement on indicators [67]. Protection of women has to be ensured through law and by setting institutions like shelter homes, assistance hotlines, medical, legal and psychological aid to the victims. Lastly, empowerment of women has to be carried out through education and participation in decision making. Women should be engaged in decision-making in sectors involved with peace and security at the national, regional and international levels. Women should be involved in all aspects of preventive diplomacy, peace negotiations, peace-keeping operations, peace-building and post-conflict reconstruction.

\section{CONCLUSIONS}

Despite scientific advancements and modernization, primitive views and beliefs exist in many different parts of the world. Societies tend to cling on to malicious beliefs with a view that it shall maintain their culture and ethnicity. HK and HBV stems from such falsely held belief systems. The problem may sound primarily social but is definitely in molten union with cultural and biological factors, yet strewed with genetic and personality factor based undercurrents. Mental health professionals, legislators, political parties and social workers need to work in unison and cooperation if they aim to eradicate the problem. The task at hand is not an easy one but steps forward on a firm footing may help future generations benefit from fruits of the labour put in by the present generation.

\section{REFERENCES}

1. Chesler P. Worldwide trends in honour killings. Middle East Quarterly 2010;Spring:3-11.

2. Niaz U. Violence against women in South Asian countries. Arch Women Ment Health 2003;6(3):173-84.

3. Oprisko RL. Honour : a phenomenology. New York: Routledge; 2012.

4. Gill A, Strange C, Roberts K. Honour killings and violence : theory, policy and practice. Palgrave Macmillan: UK ; 2014. 
5. Gill A. Honour and Honour Based Violence : challenging common assumptions. In A Gill, C Strange, K Roberts (Eds.), Honour killings and violence : theory, policy and practice (pp.127). Palgrave Macmillan: UK ; 2014.

6. Solberg KE. Killed in the name of honour. Lancet 2009;373(9679):1933-4.

7. Assembly UG. Universal declaration of human rights. UN General Assembly ; 1948.

8. Morsink J. The Universal Declaration of Human Rights : Origin, Drafting and Intent. University of Pennsylvania Press: USA ; 2011.

9. Spierenburg PC. A History of Murder : personal violence in Europe from the Middle Ages to the present. Cambridge: Polity Press ; 2008.

10. Sev'er A, Yurdakul G. Cult of honour, cult of change : a feministic analysis of honour killings in Turkey. Viol Against Women 2001;7(9):964-98.

11. Ahuja R. Social Problems in India. Jaipur: Rawat Publications ; 2006.

12. Sreenivasa Murthy HV. A History of India. Lucknow: Eastern Book Company ; 1993.

13. Jasam S. Honour, Shame and Resistance. Lahore: ASR Publications ; 2001.

14. Ali R. The Dark Side of Honour : Women Victims in Pakistan. Lahore: Shrikat Gah Women Resource Centre Pakistan ; 2001.

15. Mogadham VM. Patriarchy and politics of gender in modern societies : Iran, Pakistan and Afghanistan. Int Sociol 1992;7(1):35-53.

16. Kirti A, Kumar P, Yadav R. The face of Honour Based Crimes : global concerns and solutions. Int J Crim Justice Sci 2011;6(1\&2):343-57.

17. Hallaq WB. Shari'a : theory, practice and transformation. Cambridge: Cambridge University Press ; 2009.

18. Nabar V. Caste as Woman. New Delhi: Penguin Books ; 1995.

19. Rajshekar VT. Caste : a nation within a nation, a recipe for a bloodless revolution. Bangalore: Books for Change ; 2007.

20. Bownman J. Honour : A History. New York: Encounter Books ; 2007.

21. Srinivas MN. India : Social Structure. Delhi: Hindustan Publication Corporation ; 1991.

22. Banerjee-Dube I. Caste in History. New Delhi: Oxford University Press ; 2008.

23. Bowen P. Theories and Issues in Hinduism. London/Washington: Cassell ; 1998.

24. Critelli FM. Beyond the veil in Pakistan. J Wom Soc Work 2010;5(3):236-49.

25. Critelli FM, Willett J. Struggle and hope ; challenging gender violence in Pakistan. Crit Sociol 2012;39(2):201-21.

26. Cusack S, Cook RJ. Honour Crimes : paradigms and violence against women. Hum Rights Quart 2007;29(2):524-33.

27. Feldman S. Shame and honour : the violence of gender norms under conditions of a global crisis. Wom Stud Int Forum 2010;33(4):305-15.

28. Husseini R. Murder in the name of Honour. Oxford: One World Publications ; 2011.

29. Meetoo V, Mirza $\mathrm{H}$. There is nothing honourable about honour killing : gender, violence and the limits of multiculturalism. Wom Stud Int Forum 2007;30(3): 187-200.

30. Gill A, Brah A. Interrogating cultural narratives about honour based violence. Eur J Wom Stud 2014;21(1):79-93.

31. Thiara R, Gill A. Violence Against South Asian Women : issues for policy and prevention. London: Jessica Kingsley Publishers ; 2010.

32. Araji SK, Carlson J. Family violence including crimes of honour in Jordan. Viol Against Wom $2001 ; 7(5): 586-621$.

33. Kulwicki AD. The practice of honour crimes : a glimpse of domestic violence in the Arab world. Iss Ment Health Nurs 2002;23(1):77-87.

34. Rao M, Gangolli G, Gill A. Violence between female in laws in India. Int J Wom Stud $2013 ; 14(1): 147-60$.

35. Eisner M, Ghuneim K. Honour killing attitudes amongst adolescents in Amman, Jordan. Aggr Behav 2013;39(5):405-17.

36. Rudy D, Grusec JE. Correlation of authoritarian parenting in individualistic and collectivistic cultures and implications for the transmission of values. J Clin Child Psychol 2001;32(2):202-12. 
37. United Nations General Assembly. In depth study on all forms of violence against women. Report of the Secretary General: United Nations ; 2006.

38. Shaikh MA, Shaikh IA, Kamal A, Massood S. Attitudes about honour killings among men and women : a perspective from Islamabad. J Ayub Coll Abbottabad 2010;22(3):38-41.

39. Nasrallah M, Haqq S, Cummings KJ. Epidemiological patterns of honour killings of women in Pakistan. Eur J Pub Health 2009;19(2):193-7.

40. World Health Organization (WHO). WHO Multi-country Study on Women's Health and Domestic Violence against Women : initial results on prevalence, health outcomes and women's responses. World Health Organization: Geneva ; 2005

41. United Nations Population Fund. UNPFA Annual Report, 2000. United Nations ; 2000.

42. Warraich S. Honour Killings and the law in Pakistan. In S. Hossain, \& L. Welchman (Eds.), Honour: Crimes, Paradigms, and Violence Against Women (Pp. 78-110). London: Zed Books ; 2005.

43. Hadidi M, Kulwicki A, Jahshan H. A review of 16 cases of honour killings in Jordan in 1995. Int J Legal Med 2011;114(6):357-9.

44. Patel S, Gadit AM. Karo-kari : a form of honour killings in Pakistan. Transcult Psychiatry 2008;45(4):683-94.

45. Bhanbro S, Rafiq Wassan M, Shah MA, Talpur AA, Wassan AA. Karo-kari : the murder of honour in Sindh, Pakistan : an ethnographic study. Int J Asian Soc Sci 2013;3(7):1467-84.

46. Schwindt-Bayer LA, Mischler W. An integrated model of women's representation. J Politics 2005;67(2):407-28.

47. Wahed T, Bhuiya A. Battered bodies and shattered minds : violence against women in Bangladesh. Ind J Med Res 2001;126(4):341-54.

48. Chowdhry P. Contentious Marriages, Eloping Couples, Gender, Caste and Patriarchy in North India. Oxford: Oxford University Press ; 2007.

49. Vishwanath J, Palakonda SC. Patriarchal ideology of honour and honour crimes in India. Int J Crim Justice Sci 2009;6(1\&2):386-95.

50. Srinivas MN. India : Social Structure. Delhi: Hindustan Publication Corporation ; 1991.

51. Bandhyopadhyay D, Mukherjee A. New Issues in Panchayat Raj. Delhi: Cone Publishing Corporation ; 2004.

52. Bharadwaj SB. Myths and realities of Khap Panchayat : a historical analysis of panchayat and khap panchayat. Stud History 2012;28(1):43-67.

53. Kosambi DD. An Introduction to the Study of Indian History. Popular Prakashan: Mumbai ; 1991.

54. Singh U. Rethinking Early Medieval India : A Reader. Oxford: Oxford University Press ; 2011.

55. Rajan S. Real and Imagined Women. London: Routledge ; 1993.

56. Thapar-Bjokert S. 'If there were no khaps [...] everything will go haywire [....] young boys and young girls will start marrying into the same gotra': Understanding KhapDirected Honour Killings in Nothern India. In A. Gill, C. Strange, K. Roberts (Eds.), Honour killings and violence : theory, policy and practice (pp.156-176). Palgrave Macmillan: UK ; 2014.

57. Patel T. Sex selective abortion in India : Gender, Society and Newer Reproductive Techniques. Sage Publications: New Delhi ; 2007.

58. Singh C. Social and Economic Change in Haryana. New Delhi: National Book Organization ; 2004.

59. Reddy R. Gender, Culture and Law applicable to Honour Crimes in UK. Fem Legal Stud 2008; 16:305-21.

60. Sen A. The Argumentative Indian: Writings on Indian History, Culture and Identity. Penguin Books Limited: India ; 2006.

61. Fateh NS. Honour Killings. University of Toronto: Toronto ; 2012.

62. Doyal L. Sex, gender and health : the need for a new approach. BMJ $2001 ; 323(7320): 1061$.

63. Khan R. Honour Related Violence in Scotland: a cross and multiagency intervention involvement survey. Internet Journal of Criminology ; 2007. 
64. Lindler EG. Humiliation trauma that has been overlooked : an analysis based on fieldwork in Germany, Rwanda/Burundi and Somalia. Traumatology 2001;7(1):43-68.

65. Dickson P. Understanding victims of honour based violence. Community Practice 2014;87(7):30-3.

66. Roberts AL, Gilman SE, Breslan J, Breslan N, Koenen KC. Race / ethnic differences in exposure to traumatic events, development of post traumatic stress disorder (PTSD) and treatment seeking for PTSD in the United States. Psychol Med 2011;41(1):71-83.

67. Jewkes R. Preventing sexual violence : a rights based approach. Lancet 2002;360(9339):1092-3.

Acknowledgements - Nil.

Conflict of Interest - Nil.

Funding - Nil. 